\title{
Economic Valuation and Effectiveness of Utilizing Electrocoagulation System in Reducing Chemical Oxygen Demand of Textile Industry Wastewater
}

\author{
Elanda Fikri ${ }^{*}$, Nita Sintawati ${ }^{2}$, Tati Ruhmawati ${ }^{2}$ \\ 1 Department of Environmental Health, Bandung Health Polytechnic, 40514 Cimahi Utara, Indonesia \\ 2 Doctorate Program of Environmental Studies, Diponegoro University, 50241 Semarang, Indonesia \\ * Corresponding author's e-mail: elandafikri@yahoo.com
}

\begin{abstract}
Industrial activities vary greatly. The textile industry processes produce solid and liquid waste. The liquid waste comes from the process of reviewing threads, removing lubricants from synthetic fibers before weaving, and from the dyeing process. The purpose of this research is to determine the economic valuation and effectiveness of utilizing an electrocoagulation system in reducing Chemical Oxygen Demand (COD) of the textile industry wastewater. This research is a kind of an experimental study involving the pretest and posttest without control design. The research strategy consisted in 9 volt voltage and 5A electric current density with a $3 \mathrm{~cm}$ electrode plate distance. The container used in electrocoagulation process was made of plastic with the dimensions of $48.5 \times 27.5 \times 31 \mathrm{~cm}$. The sampling technique was grab sampling with 3 treatments and 6 repetitions. The sample size was 45 liters. The results of this research indicate that the electrocoagulation method can reduce the level of Chemical Oxygen Demand (COD) in the textile production wastewater. The COD level before treatment was $221.5 \mathrm{mg} / 1$, after electrocoagulation with 8 electrode plates dropped to $23.0-41.0 \mathrm{mg} / 1$ ( $85.26 \%$ decrease). The economic effectiveness and efficiency of the use of electrocoagulation compared to using conventional method in reducing COD level is only Rp 47.59/liter, while the conventional method reaches Rp 117.089/liter.
\end{abstract}

Keywords: economic valuation, electrocoagulation, Chemical Oxygen Demand (COD), textile industry

\section{INTRODUCTION}

Industrial activities vary greatly. Variation in the activities of industrial sector is influenced by types of raw materials processed, types of finished goods or produced materials, production capacity, techniques or types of production processes applied. One of the main types of activities producing liquid waste that has the potential of causing pollution corresponds to the textile industry activities (Soeparman and Suparmi, 2002).

The textile industry processes generate solid and liquid waste. The solid waste comes from the process of making fabrics, threads, fabric fibers, and waste from other activities that support production, while the liquid waste comes from the process of reviewing threads, removing lubricants from synthetic fibers before weaving, and from the dyeing process (Nemerow and Dasgupta 1991).

The author examined the production of liquid waste by taking samples in intermediate tank that the COD content in the liquid waste was $216.5 \mathrm{mg} / 1$ while the permissible quality standard was $150 \mathrm{mg} / 1$ (According to Ministry of Environment Regulation No.5 of 2014).

COD is an amount of oxygen $(\mathrm{mg} / \mathrm{l})$ needed to oxidize organic substances in 1 liter of water sample, where the $\mathrm{K}_{2} \mathrm{Cr}_{2} \mathrm{O}_{7}$ oxidizer is used as a source of oxygen. By measuring the value of $\mathrm{COD}$, it is possible to determine the amount of oxygen needed for the oxidation process against the total organic compounds, both those that are easily broken down biologically and on the ones that are difficult or cannot be described biologically (Barus, 2004). The high COD concentration 
causes the dissolved oxygen content in the water to be low. As a result, oxygen as a source of life for aquatic creatures (animals and plants) cannot be provided; therefore, the aquatic creature dies (Monahan, 1993).

PT. Garuda Mas Semesta WWTP uses Poly Aluminum Chloride (PAC) as a coagulant to bind turbidity and organic matter such as Chemical Oxygen Demand (COD) which is used in great amount in order that it can increase the value of the company's cost.

Coagulation can be obtained by chemical or electrical means. Chemical coagulation is now of lesser interest due to the high processing costs, producing large volume of mud, grouping of metal hydroxides as hazardous waste, and costs for chemicals that aid in coagulation. Chemical coagulation has been used for decades to destabilize suspensions and to facilitate deposition of dissolved metals. Alum, lime, and/or other polymers are commonly used chemical coagulants. This process, however, tends to produce large amounts of mud with a high content of water bonds which can slow down filtration and complicate dewatering. This process also tends to increase the content of Total Dissolve Solid (TDS) in the effluent; therefore, it cannot be used in industrial applications (Benefield, 1982).

Electrocoagulation can often neutralize particle and ion charges; therefore, it can precipitate contaminants, reduce the concentrations lower than those that can be achieved by chemical precipitation, and can replace and/or reduce the use of expensive chemicals (metal salts, polymer). Although the mechanism of electrocoagulation is similar to chemical coagulation in the case of cation species that play a role in neutralizing surface charges, the characteristics of the floc produced by electrocoagulation differ dramatically from the floc produced by chemical coagulation. The floc from electrocoagulation tends to contain little water bonds, is more stable and easier to filter (Woytowich, 1993; Fikri, 2019). After electrocoagulation, processing can be continued with flotation.

Lately, many studies have used electrocoagulation to treat synthetic wastewater as primary treatment, electrocoagulation has been chosen because it reduces the amount of sludge produced and is effective in reducing Chemical Oxygen Demand (COD); additionally, it is considered cheaper than chemical processing on primary treatment. Chemical deposition, as a preliminary treatment, gives rise to large amounts of sludge. Moreover, wastewater will contain dangerous chemicals if it enters a water body (Siregar, 2005).

According to Kuokkanen et al. (2013), electrocoagulation is a method of water treatment that combines the functions and advantages of conventional coagulation, flotation, and electrochemical processes. The electrocoagulation mechanism follows basic principle used in electrolytic cell systems, wherein the anode and cathode are located where the reduction oxidation reaction takes place. The electrical energy given to the anode dissolves aluminum into a solution which then reacts with hydroxy ions from the cathode to form hydroxy aluminum. Hydroxy coagulates and flocculates suspended particles so that the process of solid removal from water being processed occurs.

Electrocoagulation has several advantages (Letterman, 1999). For instance, the process requires simple equipment and is easy to operate. Electrocoagulation reduces the smallest content of colloid/particles faster, this is because the application of electricity into water will accelerate them in water, thereby facilitating the process; gas bubbles produced in this electrocoagulation process can carry pollutants onto the water so that they can be easily removed. It can provide an efficient process for a variety of conditions, no $\mathrm{pH}$ regulation is needed, no additional chemicals are required, while the deposits formed from the electrocoagulation process are more easily separated from water, able to move smaller colloidal particles and can regulate the electric current.

On the basis of the research results from Setianingrum (2016) pertaining to the processing of batik industry wastewater using electrocoagulation method, the efficiency of reducing COD concentration reached $71.2695 \%$ with an average distance between plates of $3 \mathrm{~cm}$. The researchers chose electrocoagulation method with aluminum anode and cathode (Al) because aluminum is a reactive electrode, a good reducing agent, corrosion resistant, cheap and easy to obtain, and can be a good coagulant.

According to the research result from Ni'am (2017), in batik industry wastewater treatment, the use of a voltage was 12 volts, the time needed was 45 minutes, and a total of 4 electrode plates used, could reduce the COD level to $61 \%$ using the electrocoagulation method. On the basis of these results, the author was interested in conducting research on the variation in the number of electrode plates in reducing the Chemical 
Oxygen Demand (COD) parameters in the textile industry wastewater.

\section{MATERIALS AND METHODS}

\section{Type of Research}

The type of research used in this study was experimental with pretest and posttest without control design, using different number of electrode plates and comparing the results with the samples that have been treated without any control (Notoatmodjo, 2010).

\section{Research Strategy}

The research strategy is carried out so that the unexpected events things which can influence the research conclusion can be avoided. Some of the things carried out in this research strategy included:

\section{Voltage}

Voltage given in the electrocoagulation process was carried out with the same voltage of 9 volts.

\section{Electric current density}

Current strength given in the electrocoagulation process was $5 \mathrm{~A}$.

3. Distance between electrodes

Distance between the electrodes was controlled by installing the electrode plate at the same distance of $3 \mathrm{~cm}$.

\section{Detention time}

The use of detention time for each tool to be tested was adjusted to the calculation. The calculation result was detention time of liquid waste production on electrocoagulation equipment that equaled 45 minutes.

\section{Electrode plate thickness}

Thickness of the electrode plate in this electrocoagulation process used the same thickness, which was $1 \mathrm{~mm}$.

6. $\mathrm{pH}$ acidity

Acidity level had to be less than 9 .

\section{Sampling Technique}

Grab sampling, carried out at the same time in one day and at the same place, was employed in the study.

\section{Sample Size}

The sample size in this study was based on the number of treatments. The number of treatment used in this study amounted to 3 , by regulating the number of plates on electrocoagulation which was used as a method to reduce the Chemical Oxygen Demand (COD) parameter in liquid waste production. In determining the sample size to be taken by author referred to the Gomez-Gomez formula. Therefore, the Gomez-Gomez formula was employed to obtain a lot of repetitions in each treatment as follows:

$$
t(r-1) \geq 15 \quad \text { (Gomez, 2007) }
$$

where: $t$ (treatment) - number of treatments (in this study there were 3 treatments), $r$ (replica)- number of repetitions.

$$
\text { Therefore: } \quad \begin{array}{ll} 
& t(r-1) \geq 15 \\
& 3(r-1) \geq 15 \\
& 3 r-3 \geq 15 \\
& 3 r \geq 18 \\
& r \geq 6
\end{array}
$$

On the basis of the calculation of GomezGomez, the number of repetitions for 3 treatments in this study that would be used was 6 repetitions.

3 treatments $\times 6$ repetitions $=18$ samples

The sample size was obtained using the following technique: the need for each treatment was $2.5 \mathrm{~L}$; therefore, the sample size for 6 repetitions: 3 treatments $\times 6$ repetitions $\times 2.5$ liters $=45$ liters

In one repetition, the COD level was tested before contacting the reactor, after contacting the reactor (effluent reactor), and was tested on the number of electrode plates.

\section{Data Collection Tool}

1. Measurement of Chemical Oxygen Demand (COD) level

2. The tools and material used were based on SNI 06 6989.73: 2009 regarding the method of testing the solids of Chemical Oxygen Demand (COD) by titrimetry.

3. Preparation of Electrocoagulation Tools 
4. Tools: reactors (glass/acrylic/polyetilene), voltmeter, pump, power supply, stopwatch, DC electric current, meter.

5. Material: Aluminum (Al) electrode plate, liquid waste produced from intermediate tank before chemical processing and afterwards from aeration tanks, $1 / 2$ inch pvc pipe, wire, and clamp.

\section{Tool Building Design}

1. Making a tank for the electrocoagulation process from the materials obtained from plastic containers with a size of $48.5 \times 27.5 \times 31$ $\mathrm{cm}$ by providing holes for effluent

2. Making plate type electrodes made of aluminum (Al) with a size of $20 \times 22 \mathrm{~cm}$

3. Stringing the wire to the electrocoagulation reactor for storing the electrode plate

4. Installing the electrode plate and wire with alligator clamp to the power supply in order to deliver electric current.

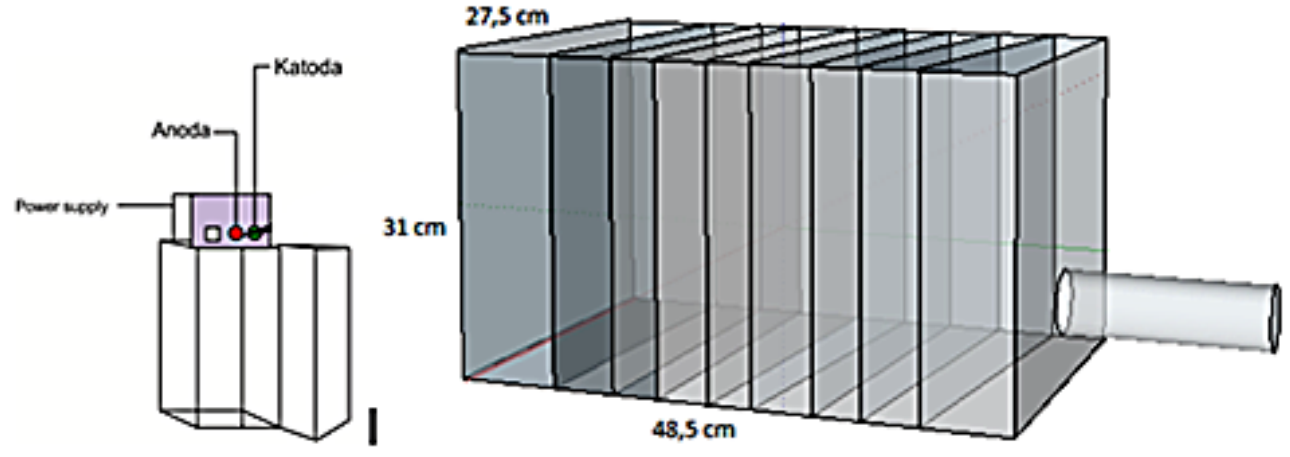

Figure 1. Electrocoagulation Tool Design

a)



b)

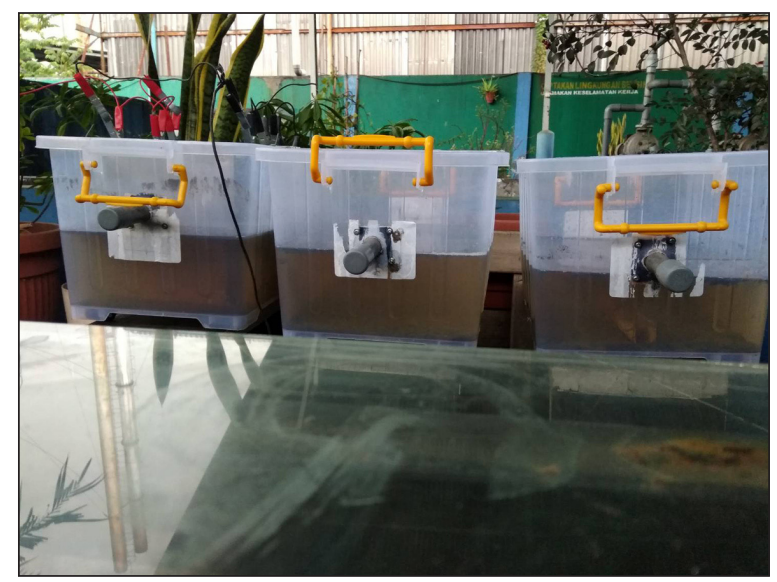

Figure 2. The electrocoagulation treatment process using 3 tanks 
a)

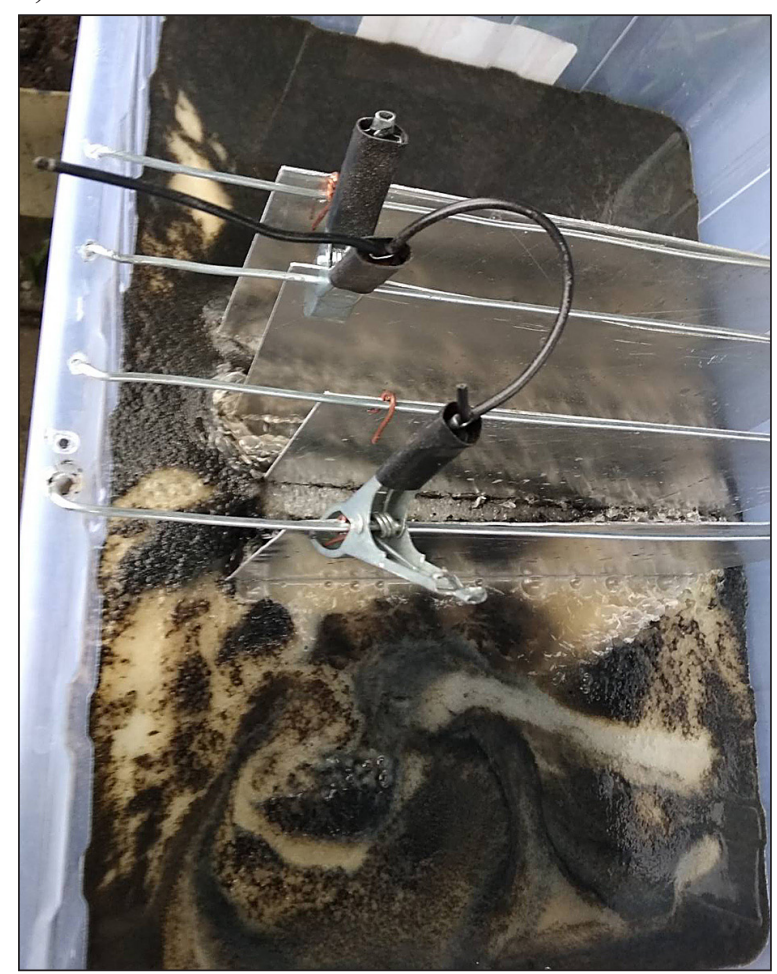

b)

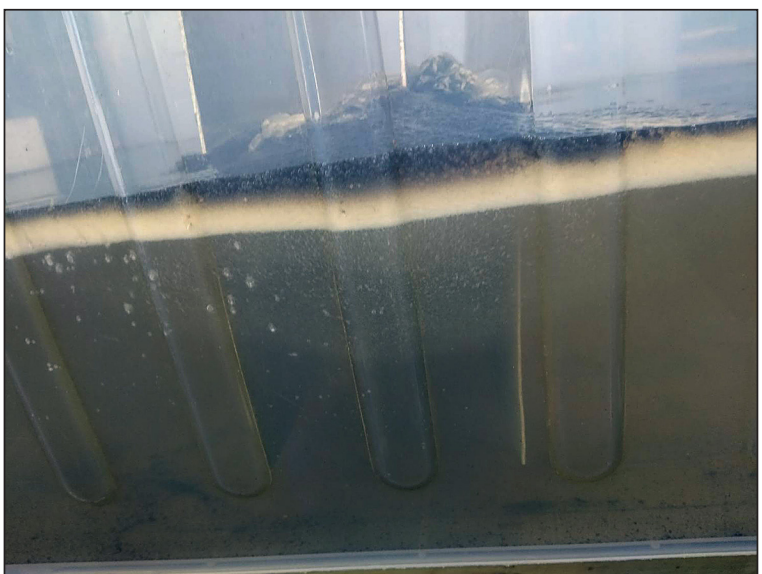

Figure 3. The resulting sludge floats on the surface, and settles over time, texture of the resulting sludge contains a lot of water.

\section{RESULTS AND DISCUSSION}

\section{The $\mathrm{pH}$ Measurement Result of the Electrocoagulation Process}

The result of temperature measurement after being processed with electrocoagulation process can be seen in Table 1 .

Table 1 indicates that the $\mathrm{pH}$ before treatment was 6.80 , after being treated with electrocoagulation process using aluminum ( $\mathrm{Al}$ ) electrode plate totaled 4 with $\mathrm{pH}$ 6.94-7.03, plate totaled 6 with $\mathrm{pH} 7.08-7.23$, and plate totaled 8 with $\mathrm{pH}$ 7.13-7.34.

This is due to the increase in the $\mathrm{pH}$ value that occurred because the electrocoagulation process accumulated OH. Nasution's research (2012) in Sillak (2015) mentioned the cathode in electrocoagulation process produced $\mathrm{OH}-$ ions which would increase the $\mathrm{pH}$ value. The $\mathrm{pH}$ value of the solution also affected the number of ions in the solution and the solubility of the product formed. $\mathrm{pH}$ of the solution affected the overall efficiency and effectiveness of electrocoagulation.

This is consistent with a research conducted by Holt (2012) who stated that the value range of 6 $<\mathrm{pH}<9$ was effective in reducing COD in textile wastewater by electrocoagulation process. The number of electrodes and the amount of voltage used affected the electrocoagulation process. Flocbinding that was bound to contaminants resulted from the interaction between electrode and voltage in the electrocoagulation process. The more floc produced the better the electrocoagulation process (Triwulandari et al., 2012).

\section{Temperature Measurement Result of Electrocoagulation Process}

The result of temperature measurement after being processed with electrocoagulation process can be seen in Table 2 .

Table 2 shows that the minimum temperature before treatment was $25.7^{\circ} \mathrm{C}$ and the maximum was $25.0^{\circ} \mathrm{C}$. After being treated with electrocoagulation process using aluminum electrode plate (Al) totaled 4 with a temperature of $25.6^{\circ} \mathrm{C}-27.0^{\circ} \mathrm{C}$, plate totaled 6 with $\mathrm{pH} 26.4^{\circ} \mathrm{C}-27.8^{\circ} \mathrm{C}$, and plate totaled 8 with $\mathrm{pH} 26.4^{\circ} \mathrm{C}-28.0^{\circ} \mathrm{C}$.

The use of electrocoagulation method could increase the temperature. Table 2 indicates that the increase in the temperature values that occurred in all treatments was in line with the increase in the number of plates used and the contact time used was 45 minutes. The temperature 
Table 1. $\mathrm{pH}$ measurement result before and after the electrocoagulation process

\begin{tabular}{|c|c|c|c|c|}
\hline \multirow{2}{*}{ Repetition } & \multirow{2}{*}{ Initial pH } & \multicolumn{3}{|c|}{ Final $\mathrm{pH}$} \\
\hline & & $4 \mathrm{Al}$ plates & 6 Al plates & 8 Al plates \\
\hline 1 & \multirow{6}{*}{6,80} & 7,0 & 7,08 & 7,17 \\
\hline 2 & & 6,98 & 7,10 & 7,13 \\
\hline 3 & & 7,01 & 7,21 & 7,26 \\
\hline 4 & & 6,94 & 7,13 & 7,21 \\
\hline 5 & & 7,0 & 7,17 & 7,29 \\
\hline 6 & & 7,03 & 7,23 & 7,34 \\
\hline
\end{tabular}

increase was caused by strong electric currents that spread to aluminum plates, direct contact to liquid waste to be processed so that temperature increased. Other factors that could affect the temperature include the air temperature during the treatment, as high air temperature would affect the liquid waste temperature.

\section{COD Measurement Result}

The result of COD measurement after treatment using electrocoagulation process with variations in the number of electrode plates can be seen in Table 3.

On the basis of Table 3, it can be seen that the initial COD data in liquid waste production before the electrocoagulation process was $221.5 \mathrm{mg} / \mathrm{l}$, while the minimum COD content after being processed by the electrocoagulation process using aluminum (Al) electrode plate with 4 plates was $73.0 \mathrm{mg} / \mathrm{l}$, with a decrease of $67 \%$, and maximum of $97 \mathrm{mg} / \mathrm{l}$ with a decrease of $56.2 \%$. In the case of 6 electrode plates, COD was $51.0 \mathrm{mg} / 1$ with a decrease of $77 \%$, and maximum of $76.8 \mathrm{mg} / \mathrm{l}$ with a decrease of $65.3 \%$. With 8 electrode plates, COD was $23.0 \mathrm{mg} / 1$ with a decrease of $89.6 \%$, and maximum of $41.0 \mathrm{mg} / 1$ with a decrease of $81.4 \%$.

It can be seen that the use of 4 plates had been able to reduce the COD concentration seen from the decrease in control to 6 repetitions, but the result did not reach its optimum, this is because there were still large electrical barriers and the electrolysis process did not run perfectly; thus, the amount of hydrogen gas produced was little. However, after the number of plates was added to

Table 2. Temperature measurement result before and after electrocoagulation process

\begin{tabular}{|c|c|c|c|c|}
\hline \multirow{2}{*}{ Repetition } & \multirow{2}{*}{$\begin{array}{c}\text { Initial temperature } \\
\left({ }^{\circ} \mathrm{C}\right)\end{array}$} & 4 Al plates & 6 Al plates & 8 Al plates \\
\cline { 3 - 5 } & 25.0 & 25,6 & 26,4 & 27.0 \\
\hline 1 & 25.0 & 25,9 & 26,2 & 26.4 \\
\hline 2 & 25.5 & 27,0 & 27,8 & 28,0 \\
\hline 3 & 25.0 & 25.7 & 27,0 & 27,5 \\
\hline 4 & 25.7 & 26.0 & 26.4 & 27.9 \\
\hline 5 & 25.2 & 26.0 & 26.7 & 27.8 \\
\hline 6 & & & \\
\hline
\end{tabular}

Table 3. Result of COD measurement before and after electrocoagulation process

\begin{tabular}{|c|c|c|c|c|c|c|c|}
\hline \multirow[b]{2}{*}{ Repetition } & \multirow{2}{*}{$\begin{array}{l}\text { Initial } \\
\text { COD } \\
\text { data } \\
\text { (mg/l) }\end{array}$} & \multicolumn{6}{|c|}{ Final Measurement } \\
\hline & & $\begin{array}{c}\mathrm{COD}(\mathrm{mg} / \mathrm{l}) \\
\text { with } 4 \text { plates }\end{array}$ & $\begin{array}{c}\text { Decrease } \\
(\%)\end{array}$ & $\begin{array}{c}\mathrm{COD}(\mathrm{mg} / \mathrm{l}) \\
\text { with } 6 \text { plates }\end{array}$ & $\begin{array}{c}\text { Decrease } \\
(\%)\end{array}$ & $\begin{array}{l}\mathrm{COD}(\mathrm{mg} / \mathrm{l}) \\
\text { with } 8 \text { plates }\end{array}$ & Decrease (\%) \\
\hline 1 & \multirow{6}{*}{221,5} & 85,5 & 61,4 & 57,2 & 74,1 & 34,2 & 84,5 \\
\hline 2 & & 73,0 & 67.0 & 56,0 & 75,0 & 26.5 & 88,0 \\
\hline 3 & & 80,1 & 64,0 & 53,5 & 76,0 & 31.0 & 86,0 \\
\hline 4 & & 91,4 & 59,0 & 64,2 & 71,0 & 39,5 & 82,1 \\
\hline 5 & & 97,0 & 56,2 & 76,8 & 65,3 & 41,0 & 81,4 \\
\hline 6 & & 76 & 65,6 & 51,0 & 77,0 & 23,0 & 89,6 \\
\hline \multicolumn{2}{|c|}{ Average } & 83.83 & 62.2 & 59.78 & 73.06 & 32.53 & 85.26 \\
\hline \multicolumn{2}{|c|}{ Minimum } & 73.0 & 56.2 & 51.0 & 65.3 & 23.0 & 81.4 \\
\hline \multicolumn{2}{|c|}{ Maximum } & 97.0 & 67.0 & 76.8 & 77.0 & 41.0 & 89.6 \\
\hline
\end{tabular}


6 plates, all the results were below threshold and the number of bubbles around the electrode plate also increased, as did the use of 8 electrode plates.

Using 8 electrode plates could produce the highest COD reduction until the existing COD concentration could meet the quality standard. Thus, it can be said that the number of electrodes influences the electrolysis process because the greater the number of plates used, the more surface area in contact will reduce the obstacles that occur. If the obstacles can be reduced then the current that exists during electrolysis becomes larger, which can ultimately maximize hydrogen gas production process itself. This data is in line with the statement put forward by Busyairi (2014) that the addition of the number of electrode plates could improve the performance of the electrolysis system. The high efficiency of TSS and COD removal on anaerobic electrolysis was caused by the type of utilized wastewater used, which originated from WWTP outlet.

Treatment using anaerobic electrolysis in reducing COD was intended to change the composition of $\mathrm{CH}_{3} \mathrm{COO}$ - ion to $\mathrm{CO}_{2}$. Wall in Cheng (2009), in general, renewable methane could be produced from methanogenesis from several substrates such as acetate, formate, and bio hydrogen gas under anaerobic conditions. In a simple anaerobic unit, it produced acidic compounds during fermentation, namely acetic acid or $\mathrm{CH}_{3} \mathrm{COO}$-. In order to reduce the COD concentration, changing $\mathrm{CH}_{3} \mathrm{COO}$ - could be done, which was a component that formed COD into methane or carbon dioxide. In order to ferment $\mathrm{CH}_{3} \mathrm{COO}$ - ion to $\mathrm{CO}_{2}$, external energy was needed, according to the following equation (Tchobanoglous, 1991):

$$
\mathrm{CH}_{3} \mathrm{COO}^{-}+4 \mathrm{H}_{2} \mathrm{O} \rightarrow 2 \mathrm{HCO}_{3}^{-}+4 \mathrm{H}_{2}+\mathrm{H}^{+}
$$

In a dark reaction, acetate could not be fertilized directly into hydrogen gas (Showell., 2006). On the basis of the reaction above, if the reaction was reversed, sufficient energy was needed to convert the acetate compounds produced in wastewater into carbon dioxide and carbonate compounds.

Increasing the number of electrode plates in electrolysis process would increase the surface area of the electrode so that it could reduce the obstacles that occurred and ultimately increased the efficiency of the electrolysis process (Utami et al, 2014). Because in this study, both the anode and the cathode used have the same material, which was carbon, the reaction that occurred in the cathode and the anode became divided into two. Since carbon itself was an inert electrode or did not react, then the reaction that occurred was:

- At the cathode:

$$
2 \mathrm{H}_{2} \mathrm{O}_{(l)}+2_{e} \rightarrow \mathrm{H}_{2(g)}+2 \mathrm{OHE}_{1}=-0.83 \mathrm{~V}
$$

- At the anode:

$$
2 \mathrm{H}_{2} \mathrm{O}_{(l)} \rightarrow 4 \mathrm{H}^{+}+\mathrm{O}_{2(g)}+4 e E=-0.40 \mathrm{~V}
$$

Thus, to calculate the total cells the following was required:

$$
\begin{aligned}
& =E 1+E 2=-0.83 \mathrm{~V} \text { to } 0.40 \mathrm{~V} \\
& =-1.23 \mathrm{~V}(\text { Nuradi, } 2017)
\end{aligned}
$$

According to Sentftle in Nuradi (2017), theoretically the energy requirement needed for electrolysis was 1.23 volts, but in fact electrolysis generally took place suddenly with low potential and resistance to produce hydrogen. The overpotential itself was the potential difference between the potential calculated in the cell and the potential occurred in the decomposition process.

In addition to changing carbon dioxide acetate with the help of hydrogen gas, the COD removal process could also be conducted by converting acetate compounds in wastewater to methane. According to Wang et al. (2009) the methane in the anaerobic process generally came from acetate $(70 \%)$ and hydrogen $(30 \%)$. The methane production itself could occur in 2 ways with conditions, namely the presence of acetate compounds, carbon dioxide, and hydrogen gas. The first method was acetoclastic methanogenesis, while the second was hydrogenotropic methanogenesis with the following equation:

- acetoclastic methanogenesis

$$
\mathrm{C}_{2} \mathrm{H}_{4} \mathrm{O}_{2} \rightarrow \mathrm{CH}_{4}+\mathrm{CO}_{2}
$$

- hydrogenotropic methanogenesis

$$
4 \mathrm{H}_{2}+\mathrm{CO}_{2} \rightarrow \mathrm{CH}_{4}+2 \mathrm{H}_{2} \mathrm{O}
$$

The use of electrocoagulation produced sludge, the resulting sludge belonged to $\mathrm{B} 3$ waste class because it had corrosive characteristics.

\section{Economic Valuation of Electrocoagulation Method}

In this case, the operational costs were calculated based on the voltage used and the time of electrolysis. On the basis of the research process 
that had been done by the author, the process ran at 9 Volt and the electrolysis time was 45 minutes so that the calculation of operational costs could be calculated as the following equation:

1. Calculation of electricity fare incurred as follows:

$$
\begin{aligned}
& \text { Voltage used }(\mathrm{V})=9 \mathrm{~V} \\
& \text { Current strength used }(\mathrm{I})=5 \mathrm{~A} \\
& \text { Contact time }(\mathrm{t}) \quad=45 \text { minutes } \\
& \text { Power }(\mathrm{P})=\mathrm{V} \times \mathrm{I} \\
& \quad=9 \text { Volt } \times 5 \text { Ampere } \\
& \quad=45 \text { Watts } \\
& \text { Electrical energy needed }(\mathrm{kWh}) \mathrm{W}=\mathrm{P} \times \mathrm{t} \\
& =45 \text { watts } \times 45 \text { minutes } \\
& \mathrm{x} \frac{1 \text { hour }}{60 \text { minutes }} \times \frac{1 \text { Kwatt }}{1000 \text { wat }}=0,03375 \mathrm{kWh}
\end{aligned}
$$

Electricity fare $=$ Rp 1,410.12/kWh (ESDM Ministry Regulation No. 31 of 2014) Electricity Costs $=\mathrm{W} \times$ Electricity fare $/ \mathrm{kWh}$

$$
\begin{aligned}
& =0.03375 \mathrm{kWh} \times \operatorname{Rp~} 1,410.12 / \mathrm{kWh} \\
& =\operatorname{Rp} 47.59 / \text { liter }
\end{aligned}
$$

a) Calculating the amount of $\mathrm{Al}$ dissolved

Weight of a soluble aluminum plate was based on the result of weighing, namely:

- Initial Al plate weight $=200.9842$ grams

- Al plate weight after processing = 200,561 grams

- SolubleAlplate weight $=200.9842-200.561$ $=0.4232$ grams $/$ liter

b) Calculating the estimated time of electrode plate replacement

$$
\begin{aligned}
& \frac{200,9842 \text { grams }}{0,4232 \text { grams }}=474,915 \text { grams } \\
& \frac{474,915 \text { grams }}{45 \text { minutes }}=10 \text { repetitions }
\end{aligned}
$$

On the basis of the calculation, the use of the electrocoagulation method in processing wastewater production cost $\mathrm{Rp} 47.59 /$ liter and the amount of dissolved aluminum was 0.4232 grams/liter in one repetition.

\section{Economic Valuation of Conventional Method}

- $1 \% \mathrm{Al}_{2} \mathrm{O}_{3}$ coagulant dose $=0.04 \mathrm{ppm}$

- Price of $100 \% \mathrm{Al}_{2} \mathrm{O}_{3}$ coagulant $=\mathrm{Rp} 880 / \mathrm{kg}$

- $\mathrm{Al}_{2} \mathrm{O}_{3}$ density $=1.37 \mathrm{~kg} / \mathrm{l}$

- Power (P) of jar test tool $=250$ watts

- Operating time $(t)=20$ minutes
- Need of $100 \% \mathrm{Al}_{2} \mathrm{O}_{3}$ coagulant to make $100 \%$ $\mathrm{Al}_{2} \mathrm{O}_{3}$ coagulant solution:

- $1 \mathrm{ml}$ of $100 \% \mathrm{Al}_{2} \mathrm{O}_{3}$ coagulant was dissolved in aquadest to a volume of $100 \mathrm{ml}$.

- $100 \% \mathrm{Al}_{2} \mathrm{O}_{3}$ coagulant weight that was needed was:

$=0.001$ liters $\times 1.37 \mathrm{~kg} /$ liter

$=0.00137 \mathrm{~kg}$ for $100 \mathrm{ml}$ of $1 \% \mathrm{Al}_{2} \mathrm{O}_{3}$ coagulant

- $100 \% \mathrm{Al}_{2} \mathrm{O}_{3}$ coagulant weight for $1 \mathrm{ml}$ of $1 \%$ $\mathrm{Al}_{2} \mathrm{O}_{3}$ coagulant $=0.0000137 \mathrm{~kg} / \mathrm{ml}$.

- For a dose of $40 \mathrm{ppm}, 4 \mathrm{ml}$ of $1 \% \mathrm{Al}_{2} \mathrm{O}_{3}$ coagulant was needed, so that the required weight of $100 \% \mathrm{Al}_{2} \mathrm{O}_{3}$ was:

$=0.0000137 \mathrm{~kg} / \mathrm{ml} \times 4 \mathrm{ml}$

$=0.0000548 \mathrm{~kg}$ to process 1 liter of sample water.

- Price of chemicals for the jar test method per liter

$=$ Alum needs $\times$ Price of alum per gram

$=0.0000548 \mathrm{~kg} / \mathrm{L} \times \mathrm{Rp} 880 / \mathrm{kg}$

$=\mathrm{Rp} 0.05 /$ liter

- Required electrical energy $(\mathrm{W}) \mathrm{W}=\mathrm{P} \times \mathrm{t}=$ 250 watts $\times 20$ minutes

$$
\frac{1 \text { hour }}{60 \text { minutes }} \times \frac{1 \text { Kwat }}{1000 \text { watt }}=0,003 \mathrm{kWh} / \mathrm{L}
$$

- Electricity fare $/ \mathrm{kwh}=\mathrm{Rp} 1,410.12 / \mathrm{kWh}$ (ESDM Ministry Regulation No. 31e of 2014)

- Total of electricity fare $=\mathrm{W} \times$ electricity $/ \mathrm{kwh}$ fare

$$
=0,003 \mathrm{kWh} / \mathrm{L} \times \mathrm{Rp} 1,410,12 \mathrm{kWh}
$$

$=\mathrm{Rp} 117,039 /$ liter

- Total price required for jar test method:

$=$ Total of electricity fare + Price of chemicals

$=\operatorname{Rp~117,039/liter~}+\mathrm{Rp} \mathrm{0.05/liter}$

$=\operatorname{Rp} 117,089 /$ liter

On the basis of the calculation pertaining to the use of the jar test method (conventional) in the processing of liquid waste production, the costs amount to Rp.117,089/liter.

\section{CONCLUSION}

1. The electrocoagulation method can reduce the level of Chemical Oxygen Demand (COD) in the textile production wastewater. The COD level before treatment was $221.5 \mathrm{mg} / \mathrm{l}$, after electrocoagulation with 4 electrode plates dropped to to $73.0-97 \mathrm{mg} / 1$ ( $62.2 \%$ decrease), the number of 6 electrode plates dropped to 
$51.0-76.8 \mathrm{mg} / 1$ (73.06\% decrease), and with 8 electrode plates dropped to $23.0-41.0 \mathrm{mg} / 1$ ( $85.26 \%$ decrease). The effect of using variations in the number of electrode plates on the changes in the COD construction is that the more electrode plates are used, the lower the amount of pollutants in liquid waste. This is because the greater the number of electrodes, the more hydrogen gas will be produced, which will then be used for the process of methanogenesis.

2. The economic effectiveness and efficiency of the use of electrocoagulation compared to using conventional method in reducing COD level is only Rp 47.59/liter, while the conventional method reaches $\mathrm{Rp}$ 117.089/liter.

\section{Acknowledgements}

This study was financially supported by Unit Penelitian dan Pengabdian Masyarakat (UPPM) Poltekkes Kemenkes RI Bandung, Ministry of Health, Indonesia scheme.

\section{REFERENCES}

1. Barus, T. A. 2004. Introduction to limnology study of mainland water ecosystems. Medan: USU Press

2. Benefield J.W., 1982. Process chemistry for water and wastewater treatment, Prentice Hall inc, New Jersey.

3. Busyairi, M., 2014. Processing of Liquid Waste with Parameters of Total Suspended Solid (TSS) and Color Using Biokoagulant (Crab Shell Waste). National Symposium RAPI XIII, FT UMS ISSN 1412-9612.

4. Fikri, E., Khalda, L.M., Pujiono. 2019. Difference of electrocoagulation contact time on sulfide decrease and color in waste water in Sipatex Putri Lesari Company, Bandung, West Java, Indonesia. Jr. of Industrial Pollution Control. 35(1), 2244-2250.

5. Holt, P. K. 2012. A quantitative comparison between chemical dosing and electrocoagulation colloids and surfaces. A: Physicochem. Eng. Aspects, 21(1), 233-248.

6. Koukkanen,M., 2013. Development of an eco-and material-efficient pellet production chain-a chemical studiy. Dissertation. University of Oulu, Oulu.

7. Letterman, R. D., Amirtharajah, A., O’Melia, C. R. 1999. Coagulation and flocculation on water quality and treatment. A Handbook of community water supplies, editor : Letterman, R. D. and American Water Works Association, McGraw-Hill, New York.
8. Monahan S.E., 1993. Fundamentals of environmental chemistry. Lewis Publishers. London.

9. Nemerow,N.L., Dasgupta, A., 1991. Industrial and hazardous waste treatment. New York: Van Nostrand Reinhold.

10. Ni'am, A.C., 2017. Variations in the amount of electrodes and large voltage in reducing COD content and TSS of textile liquid waste by electrocoagulation method. Jurnal Teknik Lingkungan. 3(1), 21-26.

11. Notoatmodjo, S. 2010. Health research methodology. Jakarta: Rineka Cipta.

12. Nuradi, R., Wiharyanto, O., Purwono. 2017. Use of anaerob electrolysis with variations of number of electrolysis and electrode plates in processing of banyumanic domestic waste waste for reduction of COD and TSS concentration. 6(1), 1-11.

13. Setianingrum, N.P., 2016. Effect of electrode and electrocoagulation method on inter-electrode voltage and distance between remazol red $\mathrm{Rb}$. Inovasi Teknik Kimia. 1(2), 93-97.

14. Showell, M.S., (2006) Introduction to Detergents dalam Handbook of Detergents Part D: Formulation, editor : Uri Zoller, Taylor \& Francis Group. Page 1-26.

15. Sillak H., Erliza, N., Yanib, M., 2015. Implementation of clean production for handling water in the oil and gas industry. Jurnal Pengelolaan Sumberdaya Alam dan Lingkungan. 5(1), 25-32.

16. Siregar,S., 2005. Waste water treatment plant. Kanisius, Yogyakarta.

17. Soeparman., Suparmi. 2002. Fecal disposal and liquid waste. Jakarta: Penerbit Buku Kedokteran EGC.

18. Wang, A., Liu, W., Cheng, S., 2009. Source of methane and methods to control its formation in single chamber microbial electrolusis cells. Int. J. Hydrogen Energy. 34, 3653-3658.

19. Woytowich. 2010. Electrocoagulation (CURE) treatment of ship bilge water for the u. s. cost guard in Alaska. Marine Technology Society Journal. 27 (2), 62-68.

20. Tchobanoglous, G. dan Burton, F.L., 1991. Wastewater engineering treatment disposal, reuse. series water resource and environmental engineering. Singapore: McGraw Hill Book.

21. Triwulandari R., Pahlevi M.N., Mirwan A., 2012. Extraction of Total $\mathrm{Cr}^{6+}$ and $\mathrm{Cr}$ Metals from Electrocoagulation Electroplating Industry Waste. Konversi. 1(1), 46-54.

22. Utami, T. S. ST, Beurabo, T.B.S., Kusuma, A.S. 2014. Test of effect of current strength, electrode distance, and electrode amount on electrocoagulation performance in reducing color and chemical oxygen demand backwash in ion exchange resin waste in PT. Refined Sugar Factory Product Angels. Jakarta: UI. 